A COMBINED BED AND FMBRGENCY COT

Gustavus M. Bl.een, M.D., Cincacio

The aceonpanying illustration shows a separable cot-led, primarily constructed for the humane transportation of sick and disabled on railrouds, improvised ambulanees, ete. bxperiments with this bed have shown it to have a distinct value in lospital pructice as well.

In the institution under my control we maintain such a bed for the reception of patients who have met some injury on the street or in the workshop. Usually these patients have soiled clothing and in spite of rubber sheeting, the linen and bedding are apt to become soiled. Should this happen on one of these beds, washing of the iron stand and laundering of the duck material is all that is necessary.

With this in mind we have used the bed also in a small number of cases of suppurating extremities, empyema of the chest, etc., and especially for patients who have lost sphincteric control. As already said, soiling of the entire bed would not ruin it.

The material on which the patient is to rest is put on very taut; at the same time it has sufficient resiliency to make it comfortable. The springs serve in this respect as an additional aid. We have noted that the tendency to decubitus is considerably lessened by this bed, which is probably explained by the ability to prevent wrinkling of the linen.

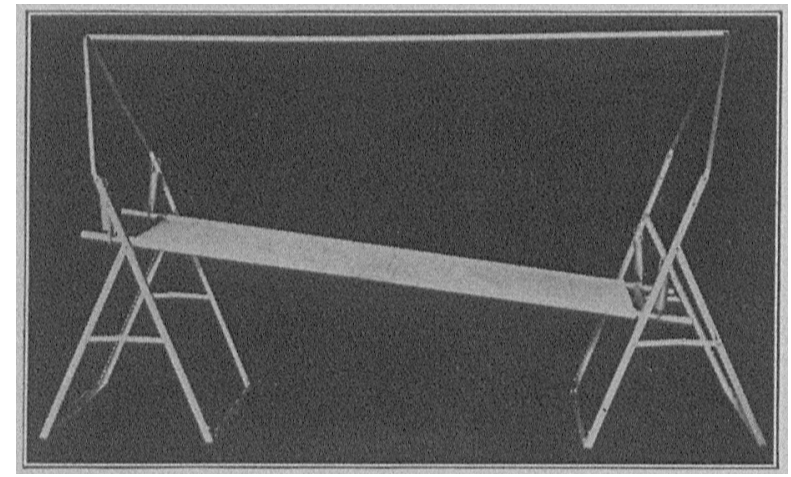

Adjustable spring cot with ntenchment for holding a canopy or a netting.

Convalescents, or patients suffering from medical and surgieal disenses requiring open-air treatment, lave been placed in good weather in the hospital yard on one of these cots. When not needed the bed is folded in a few seconds and put in some corner until needed ngain. The bed is made by the Comfort Spring Cot Co., Chicago, and costs less than the average hospital bed and a trifle more than the old-fashioned folding cots. The illustration shows an attachment for holding a canopy or a netting. This is not a part of the cot proper.

7 West Madison Street.

\section{EARLY OPERATION FOR PERIORATION IN TYPHOID FEVER}

Clakence: L. Cole, A.13., M.D., Wasilington, D. C. Captain, Medical Corps, U. S. Army

The patient who forms the sulject of this communication was treated for typhoid fever at the Post Hospital, Fort Logan, Colo., in May and June, 1911, a positive Widal reaction being obtained on the tenth day. The course of the fever way mild and the patient was returned to duty, June 27, no typhoid bacilli being found in the urine or stools at that time. He was apparently well during the month following his discharge from the hospital.

The patient was readmitted to the hospital, July 26, with a fairly high temperature and pulse, but without abslominal symptoms. He was restless and uncomfortable during the entire day of August 1 , and at about $6 \mathrm{p}$. $\mathrm{m}$. of this day he complained of a sudden, very sharp pain in the right lowet abdomen. He was sufiering severely when seen by a medical officer a few minutes later. The features were drawn and anxious, the abdomen was retracted, very rigid, extremely tew der throughout, and dull on percussion over the epigastrium. The leukocyte counts showed a rapidly progressing leukocy tosis. A diagnosis of intestinal perforation was made and the abdomen was opened at midnight, six hours after the per" foration. With but little diffieulty a perforation of a diverticulum of the small intestine was found.

This diverticulum was about 1 inch in diameter and $11 / 4$ inches in height, arising from the side of the bowel between the free margin and the mesenteric attuchment. It was united to the bowel by a short pedicle, slightly

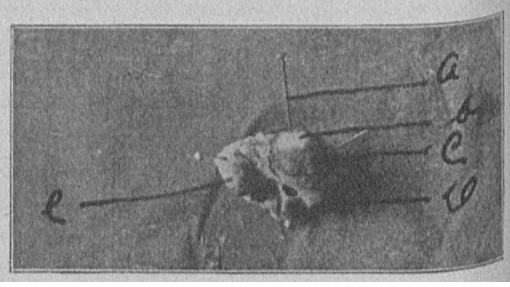

Nig. 1.-Diverticulum; $a$, pln inserted In perforation; $b$, penrly white area im medintely surrounding perforation; dirty gray exudate surrounding base of follicle; $d$, one of the smaller nodules; $e$, one of the smaller nodules. From photograpli made from the preserved specimen: less than one-half actual sizo.

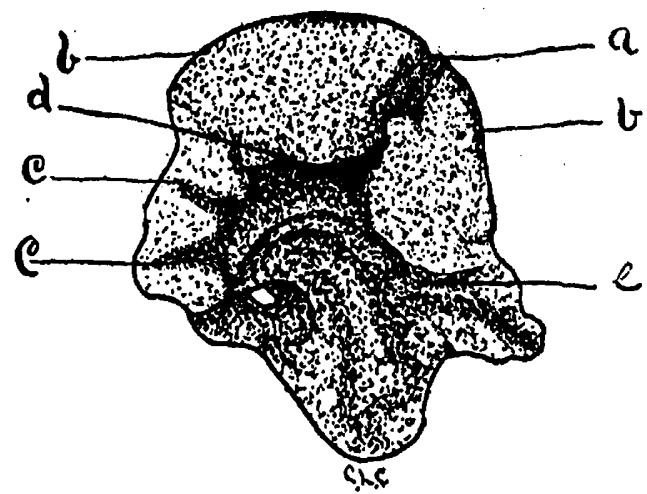

Fig. 2.-Section of lymphold follicle showing perforation; perforntion; $b$, infiltrated tissue; $c, c$, rugne in which the norma Ining of the intestinal truct is intact; $d$, a recess benentio the infiltrnted tissue whleh protrudes into the lumen of the divertict luw. From a druwing; twice actunl size.

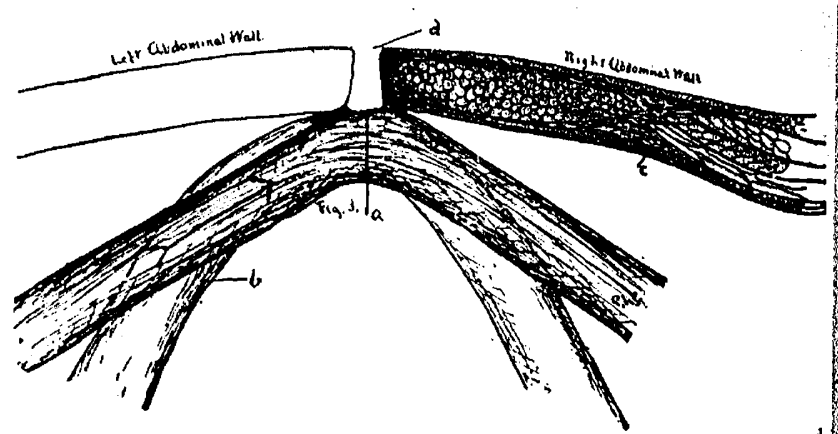

Fig. 3.-The adherent Intestine with the enterotomy would opening on the abdominal wall; $a$, wound in intestine wesultiof from enterotomy ; $b$, loop of intestine adherent in lower angle of original lifarotomy wound; $c$ abdominal pirietes; $d$, unhealed wound in abdominal parletes it center of $n$ median incision, inches in jength below umbllicus (from a druwing). No obstrut tion closing ather limb of the adherent loop of iniestine s $^{9}$ lound to exist, yet ramoval of the orclustve dropsings in the wo was rollowed by plofuse dischurge of intestinal contents.

constricted. Its dome was irregular in outline, studded with number of irregular, indurated masses or bosses. From till center of the largest of these gas was escuping, and lierc at opening about one-sixteenel inch in diameter was found.

The diverticulum was removed en masse and the wound in the bowel closed by a continuous suture with Lembert sutures Ordinary peritonenl toilet. Three large wicks of gauze vert introduced, one overlying the sutured intestine, one in the lef flank, and one to the pelvis. The inmediate course rias good 
Thirty hours after operation there was a volıntary bowel movement. Forty hours after operation definite evidences of the intestinal obstruction came on, for the relief of which was small intestine, lying at the bottom of the original wound, Decopened. Immediate relief followed this enterotomy. On December 12 a persistent fecul fistula at the site of the enterotomy opening was closed in the usual way. This procedure was followed by recovery.

Pathologic examination of the diverticulum leads to the conclusion that it was of the false or pulsion variety. Acute perforation of such a diverticulum is sufficiently uncommon to will at a report of the cuse. If it serves no other purpose it will at least call attention again to the supreme importance of an early resort to operative interference.

\section{LONGITUDINAT FRACTURE OF THE LOWER EXTREMITY OF THE RADIUS}

\section{Robert C. Parrigh, M.D., Puhlajelpila}

Clinical Assistant in Surgery, Philadelphin Polyclinic; Assistant Demonstrator of Anatomy und l'rosector to the Chalr of Anatomy, Medico-Chirurgical College

While transverse fracture of the lower end of the radius is the most frequent of all fractures, longitudinal fracture is an uncommon injury.

In 1858 at a meeting of the Boston Society for Medical Improvement, Bigelow ${ }^{1}$ showed the lower extremity of a radius which presented on its articular surface a stellate crack, with moredinal fissures rumning up the shaft for a distance of more than an inch. The patient had sustained other injuries of lam ultimately proved fatal. At first he complained only was awess of the wrist, but after several days the wrist fracture.

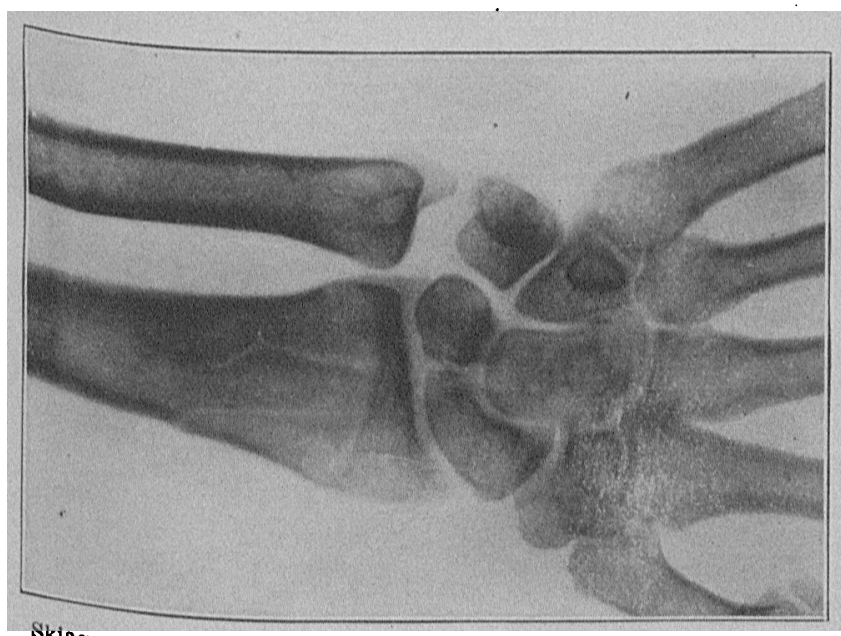

Skiagram showing longitudinal flssures in fracture of the radius.

Dr. Bigelow also reported having seen a similur case two years previously, in which the cracks were not so extended.

they very are the result of direct violence by crushing. They are

The rare; three specimens constitute the total of the evidence.

The writer has not seen such a fracture shown in the $x$-ray."

To of the eases referred to are the Bigelow cases. No ref-

rence is given for the third.

Stimson ${ }^{3}$ refer's to the Bigelow cases and states that he has

een one shown by skiagram.

fractur Beck ${ }^{2}$ and Thompson and Miles ${ }^{5}$ mentior. longitudinal any cares.

1. Bigelow, H. J.: Boston Med. nnd Surg. Jour. 1858, Iviii, 99. 3. Cotton: Dislocation and Jolnt Fractures, p. 337. 4. Stimson : Fractures and Dislocations, IAd. $5,3.290$.

5. Beck, Carl: Tructures, p. 14:.

5. Thompson and Miles: M. 14t.
The case that I have to report occurred in the service of Dr. Morris Jooth Miller at the l'hiladelphia Polyclinic, and had the following history:

T. G., aged 33, machinist, June 12, 1912, while engaged in repairing a compressed air apparatus, was struck on the wrist by a heavy piece of machinery, known as an aceumulator, which fell from a height of albout nine feet. The wrist was found to be slightly swollen and discolored, painful and decidelly tender over the lower extremity of the radius. There was no deformity, but the extreme localized tenderness suggested the probability of fracture, which was confirmed by the $x$-ray. The patient was treated on a Bond splint for three weeks, at the end of which time the wrist was in a normal condition, without stiffness or limitation of motion.

The lines of fracture are fairly well shown in the accompanying skingram.

Dr Miller has seen another case of this type of fracture in which there was a single longitudinal fissure. This fracture was caused by a window-sash falling on the wrist.

5301 Chester Avenue.

\section{OTHYGROMA NEPHRITICUM}

A HITIEERTO UNDESCRIBED DISEASE OF THE GAR-LOBE * Otto Glogau, M.D., New York

Consulting Otologist, German Odd Fellows' Orphanage; Adjunct Otolaryngologist, Bronx Hospltal ; Chief, Nose, 'lhront and liar

Iepartment, St. Mark's Hospltal, Bronx Hospltal and the

Northwestern Dlspensary; Otolaryngologlst, H. H. School and Clinte for Atypleal Children, Plainfleld, N. J.

While the auricle consists of elastic flbrocartilage covered with perichondrium and skin, the lobule is made up of skin only. The subcutaneous tissue of the lobule, although highly developed, contains within its meshes only a few vessels and nerves and many fat cells. Thus, on account of its poor vitalization, the restorative power of the lobule is rather weak.

Hypertrophy of the lobule may be congenital or acquired. If acquired, it may be eaused by certain diseases or brought about artificially. Congenital hypertrophy of the lobule is frequently encountered among the negro races. This portion of the auricle is artificinlly elongated by some savage tribes; for instance, the Botokudes introduce into the perforated lobule wooden disks of increasing size, until the lobule almost touches the shoulder. In civilized countries too an elongation of the lobule is sometimes produced in women of the poorest and richest classes by wearing large and heavy earrings.

Among pathologic conditions causing elongation of the lobule, othematoma has to be considered first. Othematoma may develop spontaneously, but is usually due to trauma. In spontaneous othematoma blood extravasates between perichondrium and cartilage of the auricle, oozing down, in some instances, into the lobule. Elongation of the lobule may also be due to elephantiasis of the entire auricle, ${ }^{1}$ or to tumor, sebaceous eyst and horny growth at this locality. Davis" published a report of a case of bilateral edema of the entire auricle of unknown cause. The disfigurement was similar to that of perichondritis of the auricle. Only a slight elongation of the lobules was present. A relatively frequent disease of the ear-lobule that causes its elongation is the so-called tubereulosis of the car-lobule, first described by Hang. In these cases no uleerntion is present. Their histologie structure is that of an epithelioid tuberele. The earlobules are elongated to the size of a walnut and show in most instances a livid discolorution. This disfigurement occurs mostly in young persons; it may be bilateral. In the center of an angioma of the lobule of twenty-two years' duration, Hang found a caseous nodule the size of a walnut.

- lead at the Seventeanth Annual Meeting of the American Acadimy of Otolaryngology, held at Ningara Falls, Ontario, Aug. $20-22,1912$.

1. Hutg: Arch, f. Ohrenh., xlli, 15.

2. Davis: Tr. Roy. Soe. Med., otol. section, 1911

3. Haug: Alch. $t$. Ohlent., xxxi! and xxxvi, 170 .

4. Haug: Arch. P. Ohrenb., xxx11, 158. 